\section{Effects of Media Porosity and Container Size on Overwintering and Growth of Ornamental Grasses}

\author{
Mary Hockenberry Meyer and Bruce A. Cunliffe \\ Department of Horticultural Science, University of Minnesota, St. Paul, \\ MN 55108
}

Additional index words. container production, growing media, aeration porosity, little bluestem, Schizachyrium scoparium, prairie dropseed, Sporobolus heterolepis, feather reedgrass, Calamagrostis ×acutiflora 'Karl Foerster', flamegrass, Miscanthus 'Purpurascens', variegated Japanese silvergrass, Miscanthus sinensis 'Variegatus'

Abstract. Five ornamental grasses \{little bluestem [Schizachyrium scoparium (Michx.) Nash], prairie dropseed [Sporobolus heterolepis (A. Gray) A. Gray], feather reedgrass [Calamagrostis x acutiflora (Schrad.) DC. 'Karl Foerster'], flamegrass (Miscanthus Anderss. 'Purpurascens'), and variegated Japanese silvergrass (Miscanthus sinensis Anderss. 'Variegatus') $\}$ were propagated by transplanting plugs or field divisions into $480-\mathrm{mL}(10-\mathrm{cm}$ round), 2.7-L (no. 1), and 6.2-L (no. 2) nursery containers with media ratios (v/v) of 0:1, $1: 1,2: 1,3: 1,1: 0$ rice hulls to sand, resulting in aeration porosities in 2.7-L containers of $5 \%, 12 \%, 22 \%, 28 \%$, and $41 \%$, respectively. Planting dates were between 28 Oct and 10 Nov. 1997; 30 Apr. and 7 May 1998; and 23-28 Oct. 1998 and 1-10 May 1999. Plants were covered with plastic and straw from the second week in November until the second week in April. Winter survival was evaluated 6 weeks after uncovering and for finished dates every 2 weeks thereafter. Species had a significant effect on overwintering survival, but container size and media did not. Sporobolus heterolepis and M. sinensis 'Variegatus' had significantly lower overwintering survival than the other species. Container size significantly influenced growth; the 6.2-L containers had the highest values for all growth parameters. Growth response to media was a weak (nonsignificant) quadratic response, indicating for these species no clear trend for the best media aeration porosity.

Container production is a vital part of the nursery industry, providing economical production methods with maximum flexibility. However, due to container constraints, plant and root environments are limited. Containers have small reservoirs for water and short substrate columns that adversely affect drainage (Fonteno, 1993).

Media characteristics may impact plant growth in containers more than in the field because of the restricted root zone in containers. Such characteristics include fertility, $\mathrm{pH}$, soluble salts, bulk density, water holding capacity, and porosity - all of which are directly influenced by the individual components used to formulate container media (Jarvis et al., 1996).

Soil aeration and the capacity to retain water are important soil properties that have been recognized for many years (McKeague, 1987). Media porosity is a significant factor affecting plant growth (Bugbee and Frink, 1986; Jarvis et al., 1996; Munoz et al., 1993).

Ornamental grasses are popular, relatively new perennials that show variability in winter hardiness (Davidson and Gobin, 1998; Meyer et al., 1995), with limited information on media, propagation, and container production (Brand, 1999; Cole and Cole, 2000; Harvey and Brand, 1999). Success in overwintering container plants may be dependent on soil

Received for publication 23 Apr. 2003. Accepted for publication 15 July 2003. Paper No. 121210104 , Minnesota Experiment Station. loamy sand-based media. Hubbard loamy sand (by volume). buds or crown diameter. Propagules were field divisions for Miscanthus 'Purpurascens' and 'Variegatus' each with three to five visible tiller buds; C. ×acutiflora 'Karl Foerster', 4cm crown diameter; and $S$. scoparium, $3-\mathrm{cm}$ crown diameter. Plug liners, grown from seed in 96-cell flats (41-mL cells), were used for S. heterolepis and S. scoparium. Propagules were planted in five different media, varied by aeration porosity.

Porosity values were determined by a simple, in situ technique (Rosen, 2000; Spomer, 1977). Containers (2.7-L) were lined with plastic and filled with dry media. The amount of water needed to fill the container and media represented the total porosity (TP). The lining was punctured and the volume of drained water represented the aeration porosity (AP). The water retention porosity (WRP) was the volume difference of AP from TP (Table 1).

Media components were composted rice hulls and Hubbard loamy sand, a field soil collected from the Sand Plain Research Farm at Becker, Minn. This field soil is characterized by a high bulk density $\left(1.28 \mathrm{~g} \cdot \mathrm{cm}^{-3}\right)$, low aeration porosity $(5 \%)$, medium acid $\mathrm{pH}$ similar to composted rice hulls (5.5), and low organic matter (Table 1). The components were mixed using volume ratios of $0: 1,1: 1$, $2: 1,3: 1$, and 1:0 rice hulls to sand, resulting in aeration porosities of $5 \%, 12 \%, 22 \%, 28 \%$, and $41 \%$, respectively. A $8-9$ month slow release $20 \mathrm{~N}-1.8 \mathrm{P}-9.1 \mathrm{~K}$ fertilizer (Woodace 20-4-11, Vigoro Industries, Chicago) was added at $5.94 \mathrm{~kg} \cdot \mathrm{m}^{-3}$. Three different container sizes: 480-mL (10-cm round), 2.7-L (no. 1), or 6.2-L (no. 2) nursery container, were used. Ten propagules were randomly assigned to each pot size and media treatment. Plants were grown on a gravel pad in full sun and watered with overhead irrigation as needed throughout the growing season. Plants were covered with two layers of plastic separated with 12 inches of straw from the second week in November until the second week in April. Due to predictable effects of container size on growth after the first year, Fall 1998 and Spring 1999 plantings involved only no. 1 (2.7-L) containers, but used the same media treatments.

Plants were evaluated for winter survival 6 weeks after uncovering and for finished dates every 2 weeks thereafter. Finish dates, defined as the date plants were determined to be saleable, have been reported (Cunliffe and Meyer, 2002). Data recorded on finished plants included height, crown diameter, shoot,

Table 1. Bulk density, aeration porosity (AP), water retention porosity (WRP), and total porosity (TP) values determined in 2.7-L containers for composted rice hull and Hubbard

\begin{tabular}{lccccc}
\hline Media & $\mathrm{pH}$ & $\begin{array}{c}\text { Bulk } \\
\text { density } \\
\left(\mathrm{g} \cdot \mathrm{cm}^{-3}\right)\end{array}$ & $\begin{array}{c}\text { TP } \\
(\%)\end{array}$ & $\begin{array}{c}\text { AP } \\
(\%)\end{array}$ & $\begin{array}{c}\text { WRP } \\
(\%)\end{array}$ \\
\hline Sand & 5.5 & 1.28 & 25 & 5 & 20 \\
$1: 1^{\mathrm{z}}$ & 5.7 & 0.81 & 41 & 12 & 29 \\
$2: 1$ & 5.7 & 0.63 & 55 & 22 & 33 \\
$3: 1$ & 5.4 & 0.52 & 63 & 28 & 35 \\
Hulls & 5.8 & 0.25 & 79 & 41 & 37 \\
\hline
\end{tabular}

${ }^{2}$ Media components were ratios of composted rice hulls to 
Table 2. Interaction between media and taxon on overwintering survival (\%) of five ornamental grasses, 1997-98, 1998-99, and 1999-2000.

\begin{tabular}{|c|c|c|c|c|c|c|c|}
\hline \multirow{2}{*}{$\begin{array}{l}\text { Media } \\
\text { components }\end{array}$} & \multicolumn{7}{|c|}{ Taxon } \\
\hline & SS-P ${ }^{z}$ & $\mathrm{SH}$ & SS-D & CALAM & VAR & PUR & Mean \\
\hline Sand & $97 a^{y, x}(a)^{w}$ & $48 \mathrm{~b}(\mathrm{c})$ & 96 a (a) & $100 \mathrm{a}(\mathrm{a})$ & $65 \mathrm{a}(\mathrm{b})$ & 94 a (a) & $84 \mathrm{a}$ \\
\hline $1: 1$ & 100 a (a) & $68 \mathrm{ab}(\mathrm{b})$ & 92 a (a) & $100 \mathrm{a}(\mathrm{a})$ & $75 \mathrm{a}(\mathrm{b})$ & 100 a (a) & $90 \mathrm{a}$ \\
\hline $2: 1$ & 100 a (a) & $72 \mathrm{ab}(\mathrm{c})$ & $90 \mathrm{a}(\mathrm{ab})$ & 97 a (a) & 76 a (bc) & 98 a (a) & $89 a$ \\
\hline $3: 1$ & 100 a (a) & $56 \mathrm{ab}(\mathrm{c})$ & 82 a (b) & $100 \mathrm{a}(\mathrm{a})$ & 79 a (b) & $90 \mathrm{a}(\mathrm{ab})$ & $85 \mathrm{a}$ \\
\hline Hulls & $100 \mathrm{a}(\mathrm{a})$ & 76 a (b) & 92 a (a) & $100 \mathrm{a}(\mathrm{a})$ & 59 a (c) & 93 a (a) & $87 \mathrm{a}$ \\
\hline Logistic $P$ values & 0.7427 & 0.0003 & 0.2680 & 0.5502 & 0.0086 & 0.2113 & \\
\hline
\end{tabular}

${ }^{2}$ SS-P = Schizachyrium scoparium plugs; $\mathrm{SH}=$ Sporobolus heterlepis $;$ SS-D = Schizachyrium scoparium

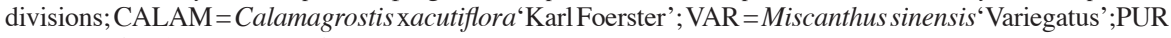
= Miscanthus 'Purpurascens'

${ }^{y}$ Means followed by the same letter are not significantly different at the $P \leq 0.05$ level.

${ }^{x}$ Letters not in parentheses indicate comparisons between media or within a column.

wetters in parentheses indicate comparisons between species or within the row.

Table 3. The effect of media on mean crown diameter and root dry weight at finished date for five ornamental grasses grown in 1997-98, 1998-99, and 1999-2000.

\begin{tabular}{lcc}
\hline $\begin{array}{l}\text { Media } \\
\text { components }\end{array}$ & $\begin{array}{c}\text { Crown diam } \\
(\mathrm{cm})\end{array}$ & $\begin{array}{c}\text { Root dry wt } \\
(\mathrm{g})\end{array}$ \\
\hline Sand & $6.57 \mathrm{~b}^{\mathrm{z}}$ & $16.9 \mathrm{~b}$ \\
$1: 1$ & $7.05 \mathrm{ab}$ & $23.7 \mathrm{a}$ \\
$2: 1$ & $7.19 \mathrm{a}$ & $20.5 \mathrm{ab}$ \\
$3: 1$ & $6.75 \mathrm{ab}$ & $21.1 \mathrm{ab}$ \\
Hulls & $6.99 \mathrm{ab}$ & $18.7 \mathrm{ab}$ \\
Quadratic & $\mathrm{NS}$ & $\mathrm{NS}$ \\
\hline
\end{tabular}

${ }^{\mathrm{z}}$ Means followed by the same letter are not significantly (NS) different at $P \leq 0.05$.

and root dry weights. Height was measured from the soil surface to the tip of the longest leaf blade. Shoots were removed at the soil surface and dried for $7 \mathrm{~d}$ in a $70{ }^{\circ} \mathrm{C}$ oven. Roots were pressure washed and dried for 7 $\mathrm{d}$ in a $70^{\circ} \mathrm{C}$ oven.

Experimental design was a randomized complete block for each of the four planting dates. Each species, media, and container had 10 replications at each planting date, except as noted above. Data were analyzed using SPSS 8.0 (SPSS, Chicago) for analysis of variance (ANOVA). Arc 1.04 software (Cook and Weisberg, 1999) was used for linear, quadratic, and logistic regression analysis. Main factors analyzed were species, media, container, and winter survival. Media and container effects on growth parameters were analyzed across all species when there was no interaction present between individual species and these factors. Multiple linear regressions were used to analyze the effect of container size on growth. Multiple quadratic regressions were used to analyze the effect of media on growth. Because survival was recorded as a binary response (dead or alive), a logistic regression was used for this analysis.

\section{Results and Discussion}

Overwintering survival was significantly lower for S. heterolepis and M. sinensis 'Variegatus', than the other taxon (Table 2). Although S. heterolepis prefers well-drained sites (Hitchcock, 1971), and had the highest winter survival in the high porosity $100 \%$ rice hull medium, this was significant only when compared to the $100 \%$ sand and low porosity, with intermediate treatments showing nonsig-
Table 4. The effect of container size on mean shoot and root dry weight at finished date for five ornamental grasses grown in 1997-98, 1998-99, and 1999-2000.

\begin{tabular}{lcc}
\hline $\begin{array}{l}\text { Container } \\
\text { size }\end{array}$ & $\begin{array}{c}\text { Shoot dry wt } \\
(\mathrm{g})\end{array}$ & $\begin{array}{c}\text { Root dry wt } \\
(\mathrm{g})\end{array}$ \\
\hline $480 \mathrm{~mL}$ & $3.4 \mathrm{a}^{\mathrm{z}}$ & $7.2 \mathrm{a}$ \\
$2.7 \mathrm{~L}$ & $10.7 \mathrm{~b}$ & $14.5 \mathrm{~b}$ \\
$6.4 \mathrm{~L}$ & $27.3 \mathrm{c}$ & $46.5 \mathrm{c}$ \\
Linear & $*$ & $*$ \\
\hline
\end{tabular}

${ }^{\mathrm{z}}$ Means followed by the same letter are not significantly different at $P \leq 0.05 ;$ * significant at $P$ $\leq 0.05$.

nificant responses (Table 2). The overwintering variability in $S$. heterolepis and $M$. sinensis 'Variegatus' appears to be related more to genetic variability rather than to media.

Three species: S. scoparium, C. ×acutiflora 'KarlFoerster' and Miscanthus 'Purpurascens', overwintered well regardless of media treatment and soil porosity (Table 2).

ANOVA and quadratic regressions were used to analyze the effect of media on growth with no clear trends (Table 3). Significant responses were noted on some individual treatments (Table 3). Pure sand had significantly lower root dry weights than the $1: 1$ media and had significantly smaller crown diameters than the $2: 1$ media. Other media treatments were not significantly different (Table 3 ).

Container size had a significant effect on root and shoot growth across all species (Table 4). Additional measurements, height, and crown diameter also showed a significant increase as the container size increased (data not shown). The effect of container size on growth was expected and appears to be strictly a function of volume. Container volume has been reported to limit basic plant growth requirements of space, water, air, and nutrients (Swanson, 1995).

Although treatments varied, there was no clear trend for container and media effects on winter survival (Table 5). Individual species showed no significant variation for these treatments and are combined for the 2 years. In the 2.7-L containers, plants in 1:1 media had a survival of $91 \%$, while those in $3: 1$ ratio had a significantly lower survival of $81 \%$. Plants in 480-mL containers had a significantly higher overwintering survival than those in 6.4-L containers in the $2: 1$ media, at $95 \%$ and $85 \%$, respectively (Table 5).

As previously reported, plants in 2.7-L containers resulted in significantly larger specimens than those in $480-\mathrm{mL}$ ones, and finished significantly sooner than those in 6.4-L containers (Cunliffe and Meyer, 2002).

Although species dependent, media aeration porosities of $10 \%$ to $20 \%$ have been found to be sufficient for most plants (Jarvis et al., 1996). Reduction in plant growth can occur when media aeration is $<10 \%$ (Bragg and Chambers, 1988; Bugbee and Frink, 1986; Goh and Haynes, 1977; Tilt and Bilderback,1987). Media with aeration porosities $>20 \%$ to $25 \%$ have shown reduced plant growth due to low water retention and increased susceptibility to drought (Bugbee and Frink, 1986).

The native sand used in this study provided a consistent medium with very low aeration, $5 \%$ (Table 1), with reduced total pore space, resulting in less air and water available to plants due to its particle size and compressive effects. Physical characteristics of media, such as pore space, bulk density, particle size distribution, and organic content, will influence porosity, water conductivity (the medium's ability to drain), and water retention. Bulk density, for example, has a slight effect on total porosity, a moderate effect on container capacity, and a major effect on aeration porosity (Fonteno, 1993). Media with small particle sizes will promote packing and reduce aeration pore volume (Jarvis et al., 1996).

As important as aeration porosity is, however, it did not show a clear trend in growth

Table 5. Interaction between media and container size on overwinter survival $(\%)$ of 5 ornamental grasses, 1997-98, 1998-99 and 1999-2000.

\begin{tabular}{lllll}
\hline Media & \multicolumn{4}{c}{ Container } \\
\cline { 2 - 5 } components & $480 \mathrm{~mL}$ & $2.7 \mathrm{~L}$ & $6.4 \mathrm{~L}$ & Mean \\
\hline Sand & $84 \mathrm{a}^{z, y}(\mathrm{a})^{\mathrm{x}}$ & $86 \mathrm{ab}(\mathrm{a})$ & $82 \mathrm{a}(\mathrm{a})$ & $84 \mathrm{a}$ \\
$1: 1$ & $85 \mathrm{a} \mathrm{(a)}$ & $91 \mathrm{a}(\mathrm{a})$ & $92 \mathrm{a}(\mathrm{a})$ & $90 \mathrm{a}$ \\
$2: 1$ & $95 \mathrm{a} \mathrm{(a)}$ & $89 \mathrm{ab}(\mathrm{ab})$ & $85 \mathrm{a}(\mathrm{b})$ & $89 \mathrm{a}$ \\
$3: 1$ & $89 \mathrm{a}(\mathrm{a})$ & $81 \mathrm{~b}(\mathrm{a})$ & $87 \mathrm{a}(\mathrm{a})$ & $85 \mathrm{a}$ \\
Hulls & $87 \mathrm{a}(\mathrm{a})$ & $86 \mathrm{ab}(\mathrm{a})$ & $89 \mathrm{a}(\mathrm{a})$ & $87 \mathrm{a}$ \\
Means & 88 (a) & 87 (a) & 87 (a) \\
\hline
\end{tabular}

${ }^{\mathrm{z}}$ Means followed by the same letter are not significantly different at $P \leq 0.05$.

y Letters not in parentheses indicate comparisons between media or within a column.

${ }^{x}$ Letters in parentheses indicate comparisons between containers or within the row. 
for the species examined in this study. The poor winter survival of $S$. heterlopis and $M$. sinensis 'Variegatus' was not significantly related to media aeration porosity in this study. Fall propagation of these two species could result in higher losses and may be a risk for commercial growers.

\section{Literature Cited}

Bragg, N.C. and B.J. Chambers. 1988. Interpretation and advisory applications of compost air-filled porosity (AFP) measurements. Acta Hort. 221:35-44.

Brand, M. 1999. Small divisions of ornamental grasses produce the best growth following direct potting. HortScience 34:1126-1128.

Bugbee, G.J. and C.R. Frink. 1986. Aeration of potting media and plant growth. Soil Sci. 141:438-441.

Cole, J. and J. Cole. 2000. Ornamental grass growth response to three shade intensities. J. Environ. Hort. 18:18-22.

Cook, R.D. and S. Weisberg. 1999. Applied regression including computing and graphics. Wiley, New York.
Cunliffe, B.A. and M.H. Meyer. 2002. Propagation time affects winter survival and finishing date for ornamental grasses. J. Environ. Hort. 20:201-203.

Davidson, C.G. and S.M. Gobin. 1998. Evaluation of ornamental grasses for the northern great plains. J. Environ. Hort. 16:218-229.

Fonteno, W.C. 1993. Problems and considerations in determining physical properties of horticultural substrates. Acta Hort. 342:197-204.

Goh, K.M. and R.J. Haynes. 1977. Evaluation of potting media for commercial nursery production of container-grown plants. N.Z. J. Agr. Res. 20:363-370.

Harvey, M. and M. Brand. 1999. Optimizing the propagation of the ornamental grass Hakonechloa macra 'Aureola'. HortScience 34:459.

Hitchcock, A.S. 1971. Manual of the grasses of the United States. 2nd ed., revised by A. Chase. Dover Publ., New York.

Jarvis, B., J.B. Calkins, and B.T. Swanson. 1996. Compost and rubber tire chips as peat substitutes in nursery container media: Effects on chemical and physical media properties. J. Environ. Hort. $14: 122-129$

McKeague, J.A. 1987. Estimating air porosity and available water capacity from soil morphology.
Soil Sci. Soc. Amer. J. 51:148-152.

Meyer, M.H., D.B. White, and H. Pellett. 1995. Ornamental grasses for cold climates. Univ. of Minnesota Expt. Sta. North Central Reg. Publ. 573.

Munoz, C., R. Soto, and J. Valenzuela. 1993. Effect of chemical and physical potting media characteristics on growth of container-grown rabbiteye blueberries. Acta Hort. 346:162-172.

Paquin, R., M. Bernier-Cardou, and Y. Castonguay. 1987. Influence of soil moisture, temperature, and length of freezing on alfalfa survival. Can. J. Plant Sci. 67:765-775.

Rosen, C.J. 2000. Compost criteria. Amer. Nurseryman 191(1):48-51.

Spomer, L.A. 1977. How much total water retention and aeration porosity in my container mix? Illinois State Florists Assoc. Bul. 369:13-15.

SPSS. 1997. Statistical packages for the social sciences. SPSS ver. 8.0 for Windows, Chicago.

Swanson, B.T. 1995. ABCs of growing medium for container production, p. 24-35. Proc. Perennial Plant Assn., Minneapolis.

Tilt, K.M. and T.E. Bilderback. 1987. Physical properties of propagation media and their effects on rooting of three woody ornamentals. HortScience 22:245-247. 